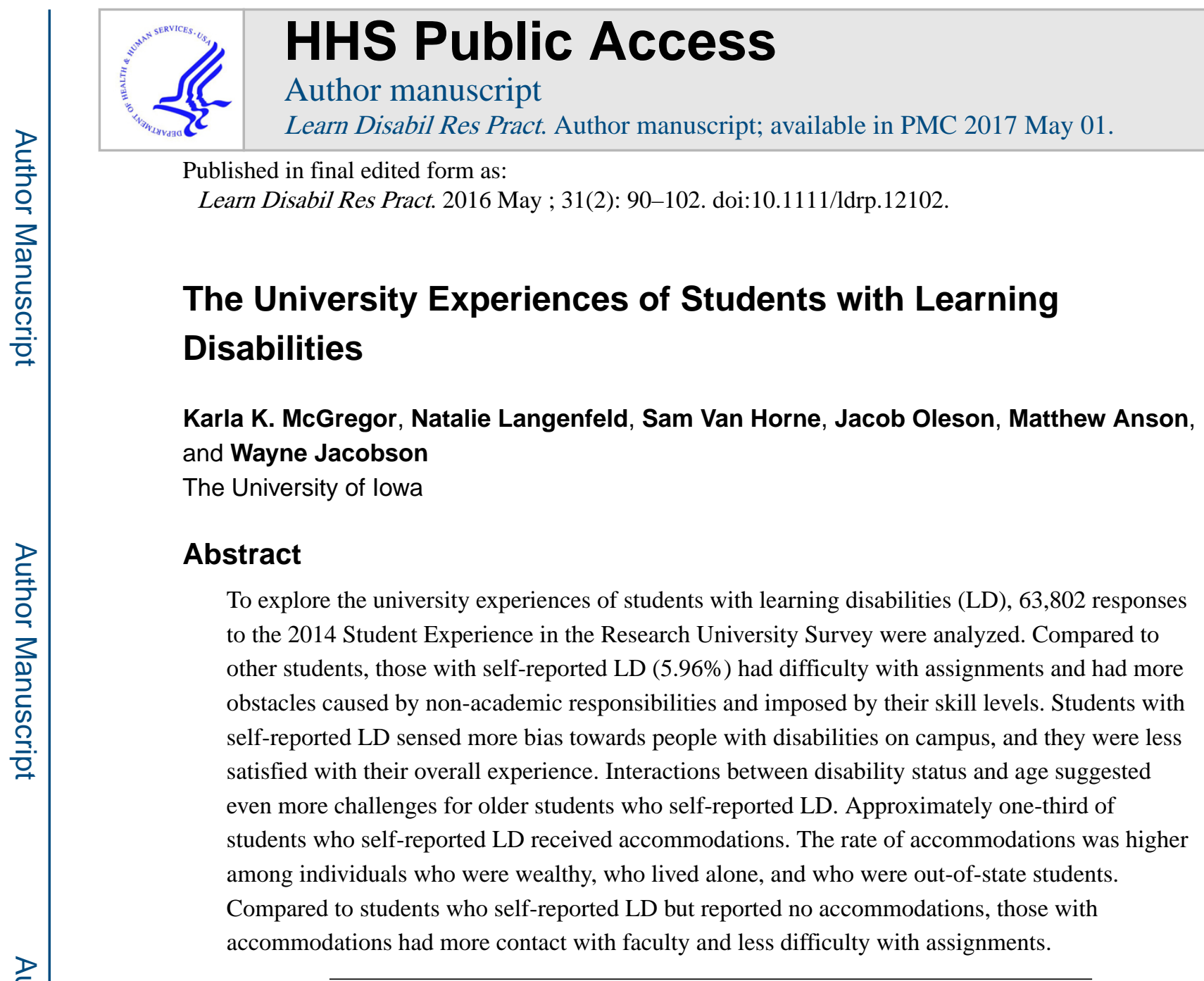

The university experience is highly individual. Students vary in engagement with the intellectual and social campus milieu, academic success, degree outcome, and overall satisfaction. One potential source of variability in the university experience is the presence or absence of a specific learning disability (LD).

The term LD denotes “... a heterogeneous group of disorders manifested by significant difficulties in the acquisition and use of listening, speaking, reading, writing, reasoning, or mathematical abilities. These disorders are intrinsic to the individual, presumed to be due to central nervous system dysfunction, and may occur across the life span" (National Joint Committee on Learning Disabilities, 1990, p. 3). Standards for identification of LD at the postsecondary level vary widely (Sparks \& Lovett, 2009), but most institutions require standardized test scores that reveal a significant discrepancy between ability and achievement, deficits in academic achievement relative to normative expectations, or underlying cognitive processing problems (Weis, Sykes, \& Unadkat, 2011).

LD is the most common type of disability reported by postsecondary students in the U.S. (American Youth Policy Forum and Center on Education Policy, 2001). At the postsecondary level, $31 \%$ of all students with disabilities have LD (Raue \& Lewis, 2011). In

Karla McGregor, Ph.D., Department of Communication Sciences and Disorders, 334 Speech and Hearing Center, Iowa City, IA 52242, karla-mcgregor@uiowa.edu, $\underline{319-335-8724}$

The authors have no financial disclosures. 
recent decades in the United States, students with disabilities of all kinds have become increasingly represented on campuses nation-wide as federal legislation, including the Individuals with Disabilities Education Act (IDEA) in 1990, its amendment in 1997, and its reauthorization in 2004, fostered greater inclusion and access to educational opportunities (Shaw, 2006). In particular, students in postsecondary studies today should have benefited from the mandate for secondary-to-postsecondary transition services included in IDEA 2004.

Nevertheless, the transition from secondary to post-secondary levels involves particular challenges for students with LD. One challenge is the disconnect between the documentation process at the secondary level, which increasingly involves a response-to-intervention approach for LD identification, and the postsecondary level, which maintains reliance on standardized tests (Madaus \& Shaw, 2004). Another challenge is the need for selfdisclosure. Whereas elementary and secondary schools are mandated to identify students with disabilities, postsecondary institutions are not. The burden is on the student to disclose and document the disability (Shaw, 2006). A third, related factor is that LD is a hidden disability and, as such, the challenges faced by students with LD are often unnoticed or misunderstood (Janiga \& Costenbader, 2002; Wolf, 2001). It is not surprising, then, that postsecondary students with LD take longer to earn a degree (Jorgensen, Fichten, Havel, Lamb, James, et al., 2007) and are more likely to leave postsecondary schooling without earning a degree (Newman et al., 2011) than other students.

\section{Access to Higher Education}

For students with disabilities, access to higher education is enabled by accommodation. Accommodation improves grades (Trammell, 2003; Troiano, Liefeld, \& Trachtenberg, 2010) and persistence to degree (Mamiseishvili \& Koch, 2010); however, only a minority of postsecondary students with LD disclose their disability to receive accommodations. For example, Newman et al. (2011) queried students who had been diagnosed with LD by secondary school staff about their disclosure rates once they entered postsecondary education. Only $24.2 \%$ disclosed their LD status to postsecondary staff; $68.9 \%$ did not disclose because they did not perceive themselves as having LD; $6.9 \%$ perceived themselves as having LD but chose not to disclose.

Cost, in both time and money, may be an obstacle to disclosure (Lightner, Kipps-Vaughan, Schulte, \& Trice, 2012), as the assessments required for documentation of LD at the postsecondary level are typically arranged and paid for by the student, not the institution (Grossman, 2001). Indeed, the prevalence of LD is higher among more affluent postsecondary students, presumably because the assessment cost is a barrier to identification for the less affluent (Vickers, 2010; Wolanin \& Steele, 2004). Qualitative interviews of students with LD in a university setting revealed poor knowledge of available accommodations, negative self-perceptions, skepticism about the usefulness of accommodations, and the wish to maintain a "typical" identity as additional reasons for not disclosing (Cole \& Cawthon, 2015). 


\section{Postsecondary Enrollment}

An exploration of the experiences of students with $\mathrm{LD}$ who pursue postsecondary education in university settings is timely. Although students with LD are now as likely as peers without disabilities to enroll in postsecondary studies, they are about twice as likely as their peers to enroll in community colleges or vocational schools, but about half as likely as their peers to enroll in 4-year colleges and universities (Newman et al., 2011; Sanford et al., 2011). In 2009 , among young adults who had been out of high school up to 8 years, $21.2 \%$ of those with LD and $40.2 \%$ of those without disabilities had enrolled in a 4-year college or university (Newman et al., 2011).

Why are universities the less frequent educational setting for students with LD? University students with LD who were interviewed by Field, Sarver, and Shaw (2003) reported the large size and impersonal nature of the university to be challenging. They found university faculty to be inaccessible, and communication with faculty and staff to be confusing. They considered community colleges to be more nurturing and supportive. Indeed, as a group, university students with LD are more successful when they begin their postsecondary careers at community colleges. Johnson, Zascavage, and Gerber (2008) reviewed the records of 85 undergraduates with LD who had received accommodations at a four-year university. Fiftyeight percent began their postsecondary education at a two-year college and then transferred; $40 \%$ began at a four-year university. Half of those who began in a two-year college environment graduated with a bachelor's degree, compared to only $26 \%$ of those who were university students from the start.

However, university students with LD attribute their educational outcomes not only to the university environment itself, but also to their strengths and weaknesses, and the familial and social supports available to them (Field et al., 2003). They acknowledge that multiple factors determine whether they meet the challenges of a university education with success or failure. Following is a conceptual framework that captures these factors.

\section{Conceptual Framework}

Models of student success in higher education posit multiple interacting factors that shape each student's experience, outcomes, and decision to persist. Astin's (1970) input-processoutcome model draws attention to the importance of both student and institutional factors in student success. The expanded theory of student involvement (Astin 1975; 1993) argues that student achievement is directly tied to the quantity and quality of student engagement in the postsecondary context. Institutions play a significant role in facilitating opportunities that increase student involvement, as well as minimizing or mitigating the effects of factors that might inhibit it.

Tinto's (1993) theory of student departure links student success to engagement of particular types. Students' decisions to persist or depart from postsecondary studies are directly shaped by the extent of their social and academic integration -- that is, the degree to which they form connections both with a community of peers who share their attitudes and values, and 
with a community of faculty who engage them intellectually in issues they perceive as relevant.

Terenzini and Reason (2014) extend the social-psychological models of Astin (1970; 1975; 1993), Tinto (1993), and others to posit a more comprehensive model of the influences on students' educational and developmental outcomes. This model involves interactions between the student's characteristics and experiences prior to postsecondary enrollment (e.g., demographic characteristics, academic preparation, and personal and social experiences), the postsecondary context itself (e.g., faculty culture, policies, academic and co-curricular programs), and the peer environment in which the individual student's experiences in and out of the classroom are embedded. The recognition that successful outcomes depend not only on the student but also on the interaction between the student and the social and academic context of the postsecondary institution is compatible with conceptualizations of $\mathrm{LD}$ as a social construction rather than a deficit that resides specifically within the individual (Reid \& Valle, 2004).

The particular factors that influence student outcomes will vary within and between subgroups of the student population. For example, Mamiseishvili and Koch (2010) examined the persistence of postsecondary students with a range of disabilities. They found that both academic and social engagement were positively associated with persistence, but demographic variables (gender, race, age), and in-university experiences (attendance intensity, grade point average [GPA], degree aspirations, and cost of attendance) were the best predictors of persistence in this broadly-defined population.

\section{Current Study}

In the current study, we aimed to document the prevalence of self-reported LD on university campuses in the United States and to discover whether disability status is associated with differences in the quality of the university experience. Additionally, we aimed to determine the proportion of students with LD who receive accommodations and to discover whether receipt of accommodations is associated with differences in the quality of the university experience. Given opportunities opened to students with LD since the passage of IDEA 2004, we predicted that prevalence would be high, but previous literature led us to predict that the rate of accommodation would be low. As one of the few large-scale studies of students with LD in universities, we did not make nuanced predictions about the influence of LD and accommodation on the quality of the university experience, but given the conceptual model, we anticipated that overall satisfaction would vary with demographic characteristics and in-university experiences.

\section{Method \\ The Data Set}

Data comprised responses to the Student Experience in the Research University survey (SERU) (Center for Studies in Higher Education, no date) administered in 2014 to undergraduates at 11 four-year doctorate-granting public universities in the U.S. The 2014 SERU survey queried undergraduates about campus climate, time expenditures, obstacles 
and supports for learning, academic success, engagement in and out of the classroom, and overall satisfaction. In other words, it provided a broad view of the undergraduate university experience as reported by the undergraduates themselves. Some questions were deemed "core" in that they were administered to all campuses, and others were deemed "modules" because they were administered to a subset of campuses. With the recognition that the university experience is best understood in terms of interactions among student background, student characteristics, institutional factors, and environmental factors, each institution supplemented students' SERU survey responses with a set of pre-university outcomes. These included high school GPA, ACT scores, the demographic variables of gender and race/ ethnicity, and in-university characteristics such as the year enrolled and whether the student is an in-state resident. Data collected through the SERU survey can provide an overview of the broad range of student experiences at an institution, and can also be disaggregated to examine experiences of particular student populations within the institution such as firstgeneration students (Stebleton, Soria, \& Huesman, 2014), recent immigrants (Stebleton, Soria, Huesman, \& Torres, 2014), service-minded students (Trolian, San Giovani, \& Jacobson, in press), and international students (Van Horne, Jacobson, \& Anson, 2014).

\section{Participants}

The universities who participated in the 2014 SERU survey were Indiana University, Purdue University, Rutgers University, Texas A\&M University, the University of Iowa, the University of Michigan, the University of Minnesota, the University of Pittsburgh, the University of Southern California, the University of Virginia, and the University of Washington. All of these institutions have more than 20,000 students, and one exceeds 65,000 students. All have competitive rather than open admission processes. The participating schools are members of the Association of American Universities, the Association that distributes the SERU survey.

In 2014, these universities distributed the SERU survey electronically to all of their currently enrolled, degree-earning undergraduates, a total of 285,436 students. Of these, 63,802 students participated, yielding a response rate of $22 \%$. The sample composition was $60.7 \%$ women and 39.3\% men. Regarding ethnicity or race, $0.4 \%$ were American Indian; $3.7 \%$ were African American; 5.7\% were Hispanic; $12.1 \%$ were Asian; $63.0 \%$ were White; $3.6 \%$ were multiracial; $6.5 \%$ were International, and $4.8 \%$ declined to state. Regarding age, $28.8 \%$ were in their teens; $68.3 \%$ were in their twenties; $2 \%$ were in their thirties, and $1 \%$ were 40 years or older.

\section{Data Analysis Approach}

The core survey contained nearly 200 questions that tapped students' academic and nonacademic experiences on campus. Two questions on the survey were critical for our analysis: "Do you have any learning disabilities that affect how you read, study, or do your coursework?" and "Do you currently receive accommodations from campus due to your disability?" The answers to these questions allowed for two sets of analyses, the first comparing the experiences of students who identified themselves as having LD to the experiences of students who identified with no disability (ND), and the second comparing 
the experiences of students who identified themselves as having LD who did, and who did not, receive accommodations.

Although all 63,802 students had the opportunity to answer the core questions, students were randomly assigned to other specific modules. Five outcome variables consisted of a composite of core questions plus questions arising from randomly assigned specific modules. If not randomly assigned to a module, any student would be considered "missing" for that outcome. The missing data mechanism can be considered Missing Completely At Random (MCAR), meaning that each subsample should then be representative of the larger sample due to randomness (Little \& Rubin, 2002). Using only the "completers" subsample would overlook important data. For example, the financial obstacles construct was comprised of eight core questions and one question from the Academic Engagement \& Global Experience module. We would be ignoring data from approximately 55,000 students by considering only the 8,400 in the module who had the opportunity to answer that specific module. Because data were assumed to be MCAR, a factor score computed as the average of the eight observed modules would be approximately equivalent to the computed factor score if all nine modules were observed and averaged.

As one of the few large-scale studies of students with LD in universities, our aims were exploratory. However, given that the large sample size allowed discovery of even subtle differences, a type one error rate at alpha less than 0.05 we deemed to be too lenient; therefore, we defined the type one error rate to be alpha less than 0.01 . We also evaluated effect sizes and disregarded those that were not meaningful. All statistical analyses were performed using SAS v9.3 software.

LD-ND Comparison-We determined the percentage of students who self-identified as having LD, and then determined whether there were over- or under-represented subgroups defined by four demographic characteristics -- (1) gender, (2) race/ethnicity, (3) SES, and (4) age -- or by nine in-university characteristics -- (1) state residency status, (2) living arrangement, (3) matriculation, (4) level in school, (5) whether the student had declared a major, (6) whether the student anticipated degree completion in the current spring or summer, (7) the year the student first registered, (8) the number of course units the student had completed at the current institution, and (9) the number of course units the student had completed overall. A chi-square test was implemented to compare groups when the outcome variable was categorical; the two-sample independent t-test was implemented when the outcome variable was continuous. Equality of variances between groups was tested using the F-test for equal variances. If the variances differed significantly, a t-test with unequal variances was used with a Satterthwaite degrees of freedom adjustment. The null hypothesis was that there was no difference between LD and ND groups in the distribution of demographic or in-university characteristics.

Next we sought to determine the effect of LD on students' university experiences as defined by 18 different constructs (see Table 1). We standardized the questions so that they were on the same scale in the same direction. We created each construct score by taking the average of the standardized question scores within the construct. Data from any person who answered at least half of the questions within a construct were used to create the score. To 
validate this scoring approach, we computed the first principal component of the questions believed to measure each of the constructs. The first principal component is the linear combination of the original questions that explains the maximum amount of variance in the original variables. If one of the questions was deemed not to measure the same construct (e.g., had a weight near zero), then it was removed from the principal component. The questions retained are available from the first author. After observing the weights, all variables contributed nearly equally to the first principal component; thus, we used a simple average of the standardized variables as our measure of the construct for further analyses. Because our measure is an average of scores, and the data are assumed to be MCAR, the assumption is reasonable. The numerical results of the principal components analysis are also available upon request.

To further validate the internal reliability of the measures, we computed Cronbach's alpha. The factors ranged in internal reliability from a low of Cronbach's alpha $=.40$ (academic time expenditures) to a high of Cronbach's alpha $=.95$ (classroom technology), with 14 of the 17 constructs having values greater than 0.69 . Note that Cronbach's alpha is technically a lower bound of the reliability of the measure (Sijtsma, 2009), and the value depends on the number of items being compared. It is being used here to showcase the degree to which the items in a construct correlate with each other, and as supporting evidence for the principal components analysis. The content of the survey limited the questions belonging to each construct, which led to some constructs having lower than desired reliability. Results from constructs with low reliability, although providing useful information, should be interpreted with caution.

We then applied a linear mixed model with LD status as a covariate and a random intercept for university to account for any within-university correlation. The 18 construct scores, expressed as standardized scores with a mean of zero and a standard deviation (SD) of one, served as outcome variables. We controlled for the 13 aforementioned demographic and inuniversity variables. Given the findings of Mamiseishvili and Koch (2010), we also controlled for interactions between $L D$ and demographic characteristics if they were significant at alpha $=.05$. As above, outcomes were deemed significant if alpha $<.01$. A pvalue less than 0.01 coincides with a $99 \%$ confidence interval around $\beta$ that does not include 0 . We reported the standardized regression coefficient $\beta$ ( $\beta$ is the change in SD units in the outcome associated with a one unit change in the predictor after controlling for all other predictors). We defined effects of less than $10 \mathrm{SD}$ difference between groups as not meaningful; $.20-.49$ as small; $.50-.79$ as moderate; and .80+ as large (Ferguson, 2009).

Accommodations-No Accommodations-We determined the percentage of students with $\mathrm{LD}$ who reported receiving accommodations. We then repeated the same analyses described above to determine whether the percentage differed between subgroups, and to discover the effect of accommodations on students' university experiences. 


\section{Results}

\section{LD - ND Comparisons}

Prevalence of LD among university students-Overall, 5.96\% $(3804 / 63,802)$ of respondents self-reported LD. Race/ethnicity was a significant point of variation, with percentages of self-reported LD noticeably lower for students identifying as Asian or International (although "international" is not a race or ethnicity, it is categorized as such on the SERU survey) and noticeably higher for students identifying as American Indian and for those who "declined to state" (see Table 2). SES was also a point of variation, with higher percentages of self-reported LD among the lowest and highest SES categories and values closer to the overall mean for the three middle SES categories. As a group, students who self-reported LD were significantly older than those who reported ND (see Table 3). The percentages of self-reported LD did not vary with gender.

Self-reported LD varied with the level in school; rates hovered around the overall rate at the Freshman and Sophomore levels and were higher at the Junior and Senior levels. Two related findings indicated that the percentage of students who identified as having LD was higher among those who had declared a major and among those who had been registered for five or more years. Disability status also varied with matriculation; notably, more than $10 \%$ of transfer students self-reported LD. Three related findings were that as a group, students who self-reported LD had completed more total units -- but no more units at the current institution -- than students who reported ND, and disability status did not vary with anticipated receipt of bachelor's degree in the following spring or summer.

The rate of LD was higher among in-state than among out-of-state students. Students living with student roommates, or with their families of origin, reported the lowest rate of LD. All other living arrangements were associated with higher rates of LD. The highest rate, 14\%, was among students who were single parents.

The effect of LD on university experiences-Next, we modeled the 18 constructs used to capture the effect of LD on the university experience (see Table 3). Eleven of these were significantly affected by disability status alone, or by an interaction between disability status and age; seven were not. Notably, the LD and ND groups did not differ on goals for their university experience or in perceived growth while at the university.

Students who self-reported LD perceived more bias against people with disabilities on their campus than those who reported ND. They also experienced more difficulty with assignments, more faculty contact outside of the classroom, more non-academic obstacles to university success, more skill-based obstacles to university success, and less satisfaction with the university experience than students who reported ND. Perceptions of bias and skillbased obstacles were the largest effects obtained (more than .33 SD), but all effects were small (less than .50 SD). It should be noted that "non-academic obstacles" was a construct with low internal validity and, as such, that finding should be considered tentative. Students with LD also engaged more often in the classroom, but this effect was too small to be meaningful. 
There were four interactions between disability status and age (Table 3). Among younger students, those who self-reported LD had lower GPAs than those who reported ND, but the opposite was true for the older population. In the ND group, with each year of age, GPA decreased by $.0225 \mathrm{SD}$, but this decrease was closer to zero in the LD group. Regardless of disability status, older students reported greater financial obstacles than younger students (see Table 3), but this was particularly true of students who had LD. For that group, the rate of increased financial obstacles with age was steeper. Younger students in the LD and ND groups reported approximately equal academic time expenditures, and these were higher than those reported by older students. The rate of decrease in academic time expenditures with age was steeper for students who reported ND than for students with LD. At younger ages, students with LD spent more time on non-academic pursuits than students who reported ND. However, for older students, the trend reversed so that students with LD spent less time on non-academic pursuits than students who reported ND. Another way to view this is that, overall, the older the student, the lower the non-academic time expenditures, but this relationship was stronger among older students who self-reported LD.

\section{Accommodation - No Accommodation Comparisons}

Nearly 33\% of students who self-reported LD received accommodations $(1251 / 3804=$ $32.9 \%$ ). Accommodations varied with one demographic characteristic, SES (see Table 4). Whereas roughly $30 \%$ of low-income, working-class, and middle-class students received accommodations, that rate rose to $36 \%$ of upper-middle-class students, and to a full $50 \%$ of wealthy students. Two in-university characteristics resulted in significant differences in the rate of accommodation as well. First, the percentage of students with and without accommodations was distributed differently according to living arrangement. Students who lived as single parents reported the lowest rate of accommodations, whereas students who lived alone reported the highest. Second, out-of-state students who self-reported LD received accommodations at a higher rate than in-state students.

The final part of our analysis was to determine if the university experience varied with accommodations (see Table 5). It did, in two ways. Students with LD who received accommodations reported less difficulty with assignments and more contact with faculty outside of the classroom than students with LD who did not have accommodations. Both effects were small. No other aspects of the university experience varied with accommodations. Most notably, accommodations were not associated with higher GPAs or higher levels of satisfaction.

That students with accommodations had less difficulty with assignments seemed at odds with the fact that GPA did not vary with accommodation status. Perhaps students with more severe LDs are the ones who seek accommodations, and those accommodations work to pull them up to the level of their peers with milder LDs. As a means of exploring this posthoc hypothesis, we ran an independent sample t-test to compare the ACT achievement scores given in the university applications of these two groups. (Some students took the SAT, but universities did not report these scores consistently, so we analyzed ACT scores only). The mean ACT score for students with accommodations was $25.88(\mathrm{n}=618)$ and the score for 
those without was $26.44(n=1150), p=0.0075, d=.13$. Therefore, students with accommodations entered university with lower levels of achievement as indexed by the ACT.

\section{Discussion}

This analysis of a survey of 63,802 students at 11 four-year doctorate-granting universities throughout the U.S. revealed self-reported LD to be a highly prevalent condition that is associated with a different and less satisfying university experience. Only a minority of students with LD had accommodations, but those who did reported more contact with faculty and less difficulty with assignments.

Nearly $6 \%$ of the undergraduates surveyed identified themselves as having LD. In survey data collected in 2003-2004, 9.3\% of undergraduates at public 4-year doctorate-granting universities self-reported a disability of any type; of those, 7.4\% self-reported LD (Horn \& Nevill, 2006). Thus, only .68\% $(.093 \times .074=.004)$ of all undergraduates at these universities self-reported LD. The prevalence of disabilities at postsecondary institutions has been on a steady increase since the introduction of the Americans with Disabilities Act (1990); nevertheless, it would be rash to conclude that the prevalence of LD has increased nearly 9-fold in just 12 years. The survey analyzed by Horn and Nevill (2006) queried nine different subtypes of disabilities (visual, hearing, speech, orthopedic, LD, ADHD, mental illness/depression, health impairments/problems, and other), whereas the SERU survey presented only a binary division (LD or physical disability). It is possible that the binary distinction forced students to consider a broader conception of LD on the SERU survey. One null finding that speaks to this possibility is the lack of gender effect in the present study. Typically, men present with LD at higher rates than women (Horn \& Nevill, 2006; Flannery, Liederman, Daly, \& Schultz, 2000; Katusic, Colligan, Barbaresi, Schaid, \& Jacobsen, 2001). A broader conception of LD may have minimized this gender difference.

It is particularly likely that, given a binary choice, students with ADHD endorsed the LD category. When it comes to the legal right to accommodation, ADHD is treated as a learning disability at postsecondary institutions (Griggins, 2005; Wilson, Getzel, \& Brown, 2000). If the LD and ADHD categories are combined, the prevalence estimate in Horn and Nevill (2006) rises to $2.1 \%$, and the rate of $6 \%$ reported here would represent a tripling over 12 years.

SES was another point of variation. The poorest and the wealthiest students had the highest rates of LD; students in working and middle classes had rates closer to the overall mean. The high rate among low-income university students is consistent with data on the prevalence of LD during childhood. Among U.S. children under 18 years, the odds of having LD are 2.66 times higher for those in the lowest income bracket (below 100\% federal poverty line) than for those in the highest income bracket (400\% or more of the federal poverty line) (Larson \& Halfon, 2010). What must be explained is the high rate among the wealthiest university students. In that subgroup, more than $10 \%$ of students self-identified as having LD. Drawing from data collected by the U.S. Department of Education, Wolanin and Steele (2004) noted that, among students with LD who are enrolled in postsecondary institutions (of any kind) and who are still dependent on their family for support, $36 \%$ hail from the highest income 
quartile. They related this phenomenon to the fact that the financial burden of hiring professionals to document LD falls on the student and family, and not on the postsecondary institution. Wolanin and Steele (2004) also explored a second explanation; that high-income students are manipulating the system to gain an academic advantage over others. Given that credible evidence is lacking, they attributed this explanation to urban legend.

Students who self-reported LD were older, on average, than those who reported ND. This point of variation likely relates to some differences in prevalence associated with inuniversity characteristics. Specifically, students who had declared a major, who were juniors or seniors, who were transfer students, and who had been registered for postsecondary studies for five or more years were over-represented in the LD population. Additionally, students who self-reported LD had completed more academic units than those who reported ND. All of these differences are consistent with the long and circuitous matriculation that characterizes many students with LD (Jorgensen et al., 2007). On average, undergraduates who report some type of disability are four years older (Horn and Nevill, 2006), and they take twice as long to complete their degree than those who reported no disability (Wolanin, 2005). Therefore, older age upon first enrollment and a longer matriculation characterize postsecondary students with disabilities in general.

Prevalence also varied with living arrangements. Single parents were over-represented in the LD population, whereas students living with student roommates, or with their families of origin, were under-represented. This finding might be related to the fact that students with LD tend to be older; therefore, they have more adult-like living arrangements than traditional undergraduates living with their parents or dorm roommates. The percentage of students who identified as having LD was higher among students attending a university within their home state than among students from out-of-state. Students with LD may prefer to remain close to their family support system and, again, this may be true for postsecondary students with disabilities in general. In Horn and Nevill (2006), undergraduates who reported some type of disability were more likely than undergraduates without disabilities to attend a postsecondary institution in-state and to live closer to their parents' homes (see U.S. Department of Education, 2014). In a recent study, 79\% of university students with reading disabilities reported parents to be critical in helping them reach their goals during their undergraduate careers (Stack-Cutler, Parrila, Jokisaari, \& Nurmi, 2015).

\section{The Experience of Students with LD}

Students who self-reported LD indicated that they had more difficulties with assignments than their peers who reported ND. Moreover, their non-academic responsibilities and their skills posed obstacles to learning. The latter seems self-explanatory; by definition, students with LD may have skill limitations that impede learning. Non-academic responsibilities may relate to the over-representation of students living as single parents or living with a significant other. Family responsibilities would demand their attention. These obstacles should be considered in light of the finding that students with LD reported more contact with professors outside of the classroom than students who reported ND. Increased contact may be a strategy employed by students with LD to compensate for obstacles to learning and success (Getzel \& Thoma, 2008). 
Students with LD also reported heightened perceptions of bias against people with disabilities on campus. The questions that comprise the bias construct involved how respected, valued, and included the student felt at his or her university as well as whether the student had heard negative or stereotypical viewpoints (about disabilities of any kind) expressed by students, staff, or faculty. Although the effect was small, this difference between students with LD and their ND peers should not be underestimated. May and Stone (2010) found that $53 \%$ of university students with LD and $38 \%$ of university students with ND believe that people stereotype individuals with LD as being less intelligent than other people. Moreover, Smart (2008) reported that students with LD and other hidden disabilities are more often suspected of malingering than students with visible disabilities. Some postsecondary students with LD feel misunderstood, devalued, marginalized, or even discriminated against (Kurth \& Mellard, 2002) and those who feel this way often choose not to seek accommodations for fear that they will be seen as taking advantage of the system, or for fear that their request will be met with a lack of empathy (Denhart, 2008).

Finally, there was a small but significant difference between LD and ND groups in overall satisfaction with the university experience. Students with LD were less satisfied with the social experience, the academic experience, the monetary value of the experience, the general campus climate, or some combination of these. Notice that these aspects of overall satisfaction are not independent of the differences reported above. Academic obstacles, nonacademic obstacles, and perceptions of bias likely inform answers to this particular SERU survey question. Smaller-scale but more in-depth interviews with university students have identified factors related to the institution itself (e.g., a campus that is too big), the curriculum (e.g., foreign language requirements), the faculty (e.g., lack of empathy), and the social context (e.g., loneliness) as impediments to satisfaction and success (Greenbaum, Graham, \& Scales, 1995). Other investigators have identified a factor not tapped by the SERU survey that might lessen satisfaction; namely, as a group, university students with LD have a lower sense of well-being than students with ND, a difference mediated by rates of anxiety and depression (Davis, Nida, Zlomke, \& Nebel-Schwalm, 2008).

Interactions between disability status and age suggest that older students with LD faced additional challenges. Although we did not predict this specific outcome, previous qualitative studies foreshadowed it. A 31-year-old woman with LD noted that the community college she attended was geared towards young students entering directly from high school. She also stated that it was painful to be working towards an undergraduate degree nearly 15 years after high school graduation (Bradshaw, 2001). A woman with LD in her late 20s shared that she continues to live with her parents, she holds two jobs in addition to attending college, and she does not participate in non-academic activities such as socializing with friends (Dodge, 2012). These are individual cases, but they are consistent with several findings in the current study: older students who self-reported LD faced more financial obstacles and had less time for non-academic pursuits, whether compared to younger students with LD or to older students who reported ND. They earned similar GPAs as older adults who reported ND, but they expended more time on academics to do so. 


\section{Accommodations}

Only $33 \%$ of students who identified as having LD reported current use of accommodations. This rate is similar to that reported by Newman et al. (2011) and Wagner, Newman, Cameto, Garza, and Levine (2005). The survey did not ask the students why they did or did not seek accommodation, but patterns in the data point to the affordability of accommodations as influential. First, fewer than $33 \%$ of low-income, working-class, and middle-class students had accommodations, but $50 \%$ of all wealthy students did. Second, the rate of accommodations was higher among out-of-state than in-state students, and this too could reflect affluence as out-of-state tuition is typically two-to-five times greater than in-state tuition (Cohen, 2011). Finally, consider that the rate of accommodation varied with living arrangement such that students who lived alone reported the highest rate of accommodation, whereas students who lived as single parents reported the lowest. Because the documentation process is time-consuming and expensive (Lightner et al., 2012), students with dependents might be less able to pursue accommodations than students without these responsibilities.

It is also possible that the decision to seek accommodations was influenced by the severity of the LD and by the academic obstacles imposed by the LD. In the current study, students with accommodations earned lower ACT scores than students without accommodations. Likewise, in Trammell (2003), the verbal SAT scores of students who self-reported LD correlated with the number of accommodations they received. Moreover, postsecondary students' most common reason for seeking accommodations is that they had begun to earn low grades (Newman et al., 2011). Those with lower achievement levels were more likely to recognize the need for accommodations and to follow through with the process of obtaining them (Cole \& Cawthon, 2015).

In the current study, there were no negative outcomes associated with receipt of accommodations. There were two indications that accommodations were associated with positive outcomes. Students with LD who had accommodations reported more contact with faculty outside of class than students with LD who did not have accommodations. This is, in part, a logical necessity. To receive accommodations, students must meet with each course instructor at the beginning of the semester to communicate the nature of the accommodation, and they often meet again periodically to arrange varied test schedules and locations or to receive course notes and outlines. However, it may also be that students motivated enough to seek accommodations are also motivated to make the extra effort to attend office hours and to take other steps towards building a relationship with the faculty. The extent to which faculty are approachable and empathetic is seen as a key determinant of success among postsecondary students with LD (Orr \& Hammig, 2009). Higher levels of informal contact with faculty can increase social integration at the university (Tinto, 1975, 1993), and this increased degree of social integration, in turn, is associated with higher persistence to university degree (DaDeppo, 2009).

\section{Limitations and Future Directions}

The primary limitation of a survey of this size is that detail is sacrificed for scope. It would be interesting, for example, to ask more nuanced questions about the type of learning 
disabilities the students report, so that a more precise estimate of prevalence may be obtained. Another limitation of this particular sample is that it is U.S.-centric. Because universities and supports for students with disabilities will vary internationally, the extent to which our findings generalize to other countries is debatable. Moreover, the U.S. institutions represented were major doctoral-granting research universities. Major research universities are characterized by a strong commitment to research that permeates not only research activities but teaching at both graduate and undergraduate levels (Group of Eight, 2013). It may be that the experiences of students with LD at universities that place less emphasis on research will differ. A final limitation concerns the response rate of $22 \%$. Low response rates are not unusual. The Personal and Social Responsibility Inventory (PSRI) is a 22-institution, campus-wide survey querying student experience and perceptions of campus climate. The response rate for a recent PSRI was 14.8\% (Barnhardt, Antonaros, Holsapple, Ott, \& Dey, 2010). In their analysis of response rates by mode of administration, Sax, Gilmartin, and Bryant (2003) found college and university freshmen to respond at a rate of $19.8 \%$ to internet surveys that lacked any response incentive. Despite being fairly typical, validity would be enhanced had a higher response rate been obtained.

Our findings present ideas for future work. Future explorations of the obstacles to receipt of accommodations are important, as the majority of students presently opt out or are denied. Additionally, studies that compare student success and satisfaction before and after receipt of accommodations in the same individuals would more accurately reveal the effect of accommodations. Finally, some attention should be paid to older students who have LD. In our sample, there were only 234 students with LD who were 30 years or older. The low numbers will make quantitative studies of this population difficult, but the frequent interactions between disability status and age in the current study point to the importance of exploring the experiences of these students in detail. Qualitative studies may be a good beginning.

\section{Conclusions and Implications}

LD is prevalent on university campuses in the U.S., yet this study confirms that universities are challenging settings for students with LD. To place the findings within the conceptual models that framed the study, one particular pre-university characteristic, having LD, influenced the university experience. One demographic characteristic, age, and one withinuniversity characteristic, receipt of accommodations, were also influential. As a group, students with LD sensed bias and obstacles to success, and they were less satisfied with their university experience than other students. That said, they did not differ in the goals they held for the university years, nor in the growth they perceived over those years.

\section{Acknowledgments}

We wish to thank Mark Harris for his support in our efforts to understand LD at the university level and Addison Stone, Teniell Trolian, Katherine Gordon and Boglarka Takacs for useful comments on a previous draft. Drs. McGregor and Oleson acknowledge the support of NIH-NIDCD 5R01DC011742 awarded to Dr. McGregor. Researchers interested in accessing the data presented here should contact Dr. Jacobson to discuss a data-sharing agreement. Those who want a list of the questions that defined each construct, the numerical results of the principal components analysis, or the visual representations of the interaction effects should contact Dr. McGregor. 


\section{Biography}

About the Authors. Karla K. McGregor earned a Ph.D. from Purdue University. She is a professor in the Department of Communication Sciences and Disorders at The University of Iowa where she conducts research on language learning disabilities. Natalie Langenfeld earned a M.S degree from Southern Illinois University Edwardsville. She is currently pursuing a Ph.D. from the University of Iowa where she teaches Introduction to Biostatistics and conducts research on Bayesian hierarchical models of correlated data including spatiotemporal models for infectious disease processes. Sam Van Horne received his Ph.D. from the Department of Teaching and Learning in the College of Education at the University of Iowa where he now holds a joint appointment in the Office of Assessment and in the Office of Teaching, Learning and Technology. His research interests include students' abilities to regulate their learning in educational technology applications as well as the factors associated with college student success. Jacob Oleson earned his Ph.D. from the University of Missouri at Columbia. He is an associate professor of biostatistics in the College of Public Health at the University of Iowa and the Director of the Center for Public Health Statistics. He conducts both biostatistical methodologic research and collaborative clinical research. His current research activities are focused on Bayesian hierarchical models of correlated data including spatio-temporal models for infectious disease processes and longitudinal data arising from studies in communication sciences and disorders. Wayne Jacobson holds a Ph.D. from the University of Wisconsin - Madison. He serves as Assessment Director in the Office of the Provost and holds an adjunct faculty appointment in Educational Policy and Leadership Studies at the University of Iowa.

\section{References}

Americans with Disabilities Act of 1990, 42 U.S.C. §12101 et seq. 1990.

American Youth Policy Forum and Center on Education Policy. Twenty-five Years of Educating Children with Disabilities: The Good News and the Work Ahead. Washington, DC: 2001.

Astin A. College influence: A comprehensive view. Contemporary Psychology. 1970; 15(9):543-546.

Astin, A. Preventing students from dropping out. Jossey-Bass; San Francisco, CA: 1975.

Astin, A. What matters in college? Four critical years revisited. Jossey-Bass; San Francisco: 1993.

Barnhardt, C.; Antonaros, M.; Holsapple, MA.; Ott, MC.; Dey, EL. The PSRI Technical Guide. Association of American Colleges and Universities; Washington, DC: 2010.

Bradshaw, YM. Case studies of postsecondary college students with learning disabilities. 2001. (Doctoral dissertation). Retrieved from http://scholar.lib.vt.edu

Center for Studies in Higher Education. SERU Student Experience in the Research University; no datehttp://www.cshe.berkeley.edu/SERU

Cohen, S. The out-of-state admissions edge. The Daily Beast. 2011. http://www.thedailybeast.com/ articles/2011/08/18/college-admissions-which-state-schools-give-an-edge-to-out-of-statestudents.html

Cole EV, Cawthon SW. Self-disclosure decisions of university students with learning disabilities. Journal of Postsecondary Education and Disability. 2015; 28(2):163-179.

DaDeppo LM. Integration factors related to the academic success and intent to persist of college students with learning disabilities. Learning Disabilities Research \& Practice. 2009; 24(3):122131.

Davis K. Intersectionality as Buzzword: A Sociology of Science Perspective on What Makes a Feminist Theory Successful. Feminist Theory. 2008; 9:67-85. 
Davis TE III, Nida RE, Zlomke KR, Nebel-Schwalm MS. Health-related quality of life in college undergraduates with learning disabilities: The mediational roles of anxiety and sadness. Journal of Psychopathology and Behavioral Assessment. 2009; 31(3):228-234.

Denhart H. Deconstructing barriers: perceptions of students labeled with learning disabilities in higher education. Journal of Learning Disabilities. 2008; 41(6):483-497. [PubMed: 18931016]

Dodge, KM. Examining the lived experience of students with reading comprehension learning disabilities and the perceived value of the accommodations received. 2012. (Doctoral dissertation). Retrieved from http://utdr.utoledo.edu/theses-dissertations

Ferguson CJ. An effect size primer: A guide for clinicians and researchers. Professional Psychology: Research and Practice. 2009; 40(5):532.

Field S, Sarver MD, Shaw SF. Self-determination. [A key to success in postsecondary education for students with learning disabilities.]. Remedial and Special Education. 2003; 24:339-349. doi: 10.1177/07419325030240060501.

Flannery KA, Liederman J, Daly L, Schultz J. Male prevalence for reading disability is found in a large sample of black and white children free from ascertainment bias. Journal of the International Neuropsychological Society. 2000; 6(4):433-442. [PubMed: 10902412]

Getzel EE, Thoma CA. Experiences of college students with disabilities and the importance of selfdetermination in higher education settings. Career development for exceptional individuals. 2008; 31(2):77-84.

Greenbaum B, Graham S, Scales W. Adults with learning disabilities: Educational and social experiences during college. Exceptional Children. 1995; 61(5):460-471.

Griggins C. Dosing dilemmas: are you rich and white or poor and black? The American Journal of Bioethics. 2005; 5(3):55-57. [PubMed: 16006374]

Grossman PD. Making accommodations: the legal world of students with disabilities. Academe. 2001; 87(6):41-46.

Group of Eight. Hefei statement on the ten characteristics of contemporary research universities. 2013. Downloaded from https://go8-dev.launchpad.agileware.com.au/article/hefei-statement-10characteristics-contemporary-research-universities

Horn, L.; Nevill, S. Profile of undergraduates in U.S, postsecondary education institutions: 2003-04: With a special analysis of community college students. U.S. Department of Education, National Center for Education Statistics; Washington, DC: 2006. NCES 2006-184

Janiga SJ, Costenbader V. The transition from high school to postsecondary education for students with learning disabilities: A survey of college service coordinators. Journal of Learning Disabilities. 2002; 35(5):463-470.

Johnson G, Zascavage V, Gerber S. Junior college experience and students with learning disabilities: Implications for success at the four year university. College Student Journal. 2008; 42:1162-1168.

Jorgensen S, Fichten CS, Havel A, Lamb D, James C, Barile M. Academic performance of college students with and without disabilities: An archival study. Canadian Journal of Counselling and Psychotherapy. 2007; 39(2) Retrieved from http://cjc-rcc.ucalgary.ca/cjc/index.php/rcc/article/ view/272.

Katusic SK, Colligan RC, Barbaresi WJ, Schaid DJ, Jacobsen SJ. Incidence of reading disability in a population-based birth cohort, 1976-1982, Rochester, Minn. Mayo Clinic Proceedings. 2001; 76:1081-1092. [PubMed: 11702896]

Kurth N, Mellard D. Student perceptions of the accommodation process in postsecondary education. The Journal of Postsecondary Education and Disability. 2006; 19(1):71-84.

Larson K, Halfon N. Family income gradients in the health and health care access of US children. Maternal and Child Health Journal. 2010; 14(3):332-342. [PubMed: 19499315]

Lightner KL, Kipps-Vaughan D, Schulte T, Trice AD. Reasons university students with a learning disability wait to seek disability services. Journal of Postsecondary Education and Disability. 2012; 25(2):159-177.

Little, RJA.; Rubin, DB. Statistical Analysis with Missing Data. second edition. John Wiley \& Sons; Hoboken, NJ: 2002.

Madaus JW. Employment outcomes of university graduates with learning disabilities. Learning Disability Quarterly. 2006; 29:19-31. doi: 10.2307/30035529. 
Madaus JW, Shaw SF. Section 504 Differences in the Regulations for Secondary and Postsecondary Education. Intervention in School and Clinic. 2004; 40(2):81-87.

Mamiseishvili K, Koch LC. First-to-second-year persistence of students with disabilities in postsecondary institutions in the United States. Rehabilitation Counseling Bulletin. 2010; 54(2): 93-105.

May AL, Stone CA. Stereotypes of individuals with learning disabilities: Views of college students with and without learning disabilities. Journal of learning disabilities. 2010; 43:483-499. [PubMed: 20375292]

National Joint Committee on Learning Disabilities. Learning Disabilities: Issues on Definition. 1990. Retrieved from http://www.ldonline.org/about/partners/njcld/archives

Newman, L.; Wagner, M.; Knokey, A-M.; Marder, C.; Nagle, K.; Shaver, D.; Schwarting, M. The posthigh school outcomes of young adults with disabilities up to 8 years after high school. 2011. [A report from the National Longitudinal Transition Study-2 (NLTS2)]. NCSER 2011-3005. Retrieved from http://www.nlts2.org/reports

Orr AC, Hammig SB. Inclusive postsecondary strategies for teaching students with learning disabilities: A review of the literature. Learning Disability Quarterly. 2009; 32(3):181-196.

Raue, K.; Lewis, L.; U.S. Department of Education, National Center for Education Statistics. Students with Disabilities at Degree-Granting Postsecondary Institutions. U.S. Government Printing Office; Washington, DC: 2011. NCES 2011-018

Reid DK, Valle JW. The discursive practice of learning disability: Implications for instruction and parent-school relations. Journal of Learning Disabilities. 2004; 37(6):466-481. [PubMed: 15586465]

Sanford, C.; Newman, L.; Wagner, M.; Cameto, R.; Knokey, AM.; Shaver, D. The Post-High School Outcomes of Young Adults with Disabilities up to 6 Years after High School: Key Findings from the National Longitudinal Transition Study-2 (NLTS2). National Center for Special Education Research; 2011. NCSER 2011-3004

SAS 9.3 [Computer software]. Copyright (C) 2002-2010. SAS Institute Inc.; Cary, NC:

Sax LJ, Gilmartin SK, Bryant AN. Assessing response rates and nonresponse bias in web and paper surveys. Research in Higher Education. 2003; 44(4):409-432.

Shaw S. Legal and policy perspectives on transition assessment and documentation. Career Development for Exceptional Individuals. 2006; 29(2):108-113.

Sijtsma K. On the use, the misuse, and the very limited usefulness of Cronbach's alpha. Psychometrika. 2009; 74:107-120. [PubMed: 20037639]

Smart, JF. Disability, society, and the individual. 2nd ed.. Pro Ed.; Austin, TX: 2008.

Sparks RL, Lovett BJ. College students with learning disability diagnoses. [Who are they and how do they perform?]. Journal of Learning Disabilities. 2009; 42:494-510. doi: 10.1177/0022219409338746. [PubMed: 19704046]

Stack-Cutler HL, Parrila RK, Jokisaari M, Nurmi JE. How university students with reading difficulties are supported in achieving their goals. Journal of Learning Disabilities. 2015; 48(3):323-34. [PubMed: 24127482]

Stebleton M, Soria K, Huesman R. First-generation students' sense of belonging, mental health, and use of counseling services at public research universities. Journal of College Counseling. 2014; 17(1):6-20.

Stebleton M, Soria K, Huesman R, Torres V. Recent immigrant students at research universities: The relationship between campus climate and sense of belonging. Journal of College Student Development. 2014; 55(2):196-202.

Terenzini, PT.; Reason, RD. Rethinking between-college effects on student learning: A new model to guide assessment and quality assurance. In: Yamada, R., editor. Measuring Quality of Undergraduate Education in Japan. Springer; Singapore: 2014. p. 59-73.

Tinto, V. Leaving college: Rethinking the causes and cures of student attrition. 2nd ed.. University of Chicago Press; Chicago, IL: 1993.

Trammell JK. The impact of academic accommodations on final grades in a postsecondarysetting. Journal of College Reading and Learning. 2003; 34(1):76-89. 
Troiano PF, Liefeld JA, Trachtenberg JV. Academic support and college success for postsecondary students with learning disabilities. Journal of College Reading and Learning. 2010; 40:35-44. doi: 10.1080/10790195.2010.10850329.

Trolian, T.; San Giovani, S.; Jacobson, W. Belonging and Satisfaction of Service-Minded Students at Research Universities. In: Soria, K.; Mitchell, T., editors. Revisiting the Civic Mission of the American Public Research University. Palgrave Macmillan; New York: in press

U.S. Department of Education. Profile of Undergraduate Students: 2011-12. 2014. Web Tables. NCES 2015-167

Van Horne, S.; Jacobson, W.; Anson, M. International Students and Engagement in the Research University; Annual Conference of the Professional and Organizational Development Network in Higher Education (POD); Dallas, TX. 2014, November;

Vickers, MZ. Accommodating college students with learning disabilities: ADD, ADHD, and dyslexia. John W. Pope Center for Higher Education Policy; Raleigh, NC: 2010. Retrieved from http:// www.popecenter.org/acrobat/vickers-mar2010.pdf

Wagner M, Newman L, Cameto R, Garza N, Levine P. After high school: A first look at the postschool experiences of youth with disabilities. A report from the National Longitudinal Transition Study-2 (NLTS2). Online Submission. 2005

Weis R, Sykes L, Unadkat D. Qualitative differences in learning disabilities across postsecondary institutions. Journal of Learning Disabilities. 2011; 45:491-502. doi: 10.1177/0022219411400747. [PubMed: 21421937]

Wilson K, Getzel E, Brown T. Enhancing the postsecondary campus climate for students with disabilities. Journal of Vocational Rehabilitation. 2000; 14(1):37-50.

Wolanin TR. Students with disabilities: Financial aid policy issues. Journal of Student Financial Aid. 2005; 35(1):2.

Wolanin, TR.; Steele, PE. Higher education opportunities for students with disabilities: A primer for policymakers. The Institute for Higher Education Policy; Washington, DC: 2004.

Wolf LE. College students with ADHD and other hidden disabilities. Annals of the New York Academy of Sciences. 2001; 931(1):385-395. [PubMed: 11462755] 
Table 1

\section{Constructs used to capture the students' university experience}

\begin{tabular}{|c|c|}
\hline Construct & Definition \\
\hline Active engagement & $\begin{array}{l}\text { Frequency of participating in class, going beyond } \\
\text { minimum requirements, selecting challenging courses }\end{array}$ \\
\hline Bias & $\begin{array}{l}\text { Degree to which student perceives bias against } \\
\text { disabilities on campus }\end{array}$ \\
\hline Difficulty w/ assignments & $\begin{array}{l}\text { Frequency of late or incomplete work and skipped } \\
\text { classes }\end{array}$ \\
\hline Enriched academic experience & $\begin{array}{l}\text { Extent of participation in learning activities outside of } \\
\text { the normal classroom experience }\end{array}$ \\
\hline Faculty contact & $\begin{array}{l}\text { Frequency of interaction with faculty in and out of the } \\
\text { classroom }\end{array}$ \\
\hline Goals & $\begin{array}{l}\text { What student would like to achieve as a result of the } \\
\text { university experience }\end{array}$ \\
\hline Grade point average & Cumulative GPA \\
\hline Major & $\begin{array}{l}\text { Student's judgment of factors important in deciding } \\
\text { upon a major }\end{array}$ \\
\hline Obstacles: Financial & $\begin{array}{l}\text { Extent of concerns about debt and the cost of } \\
\text { university; extent to which paid employment impedes } \\
\text { academic success }\end{array}$ \\
\hline Obstacles: Non-academic & $\begin{array}{l}\text { Extent to which extracurricular activities, family } \\
\text { obligations, or military service impedes academic } \\
\text { success }\end{array}$ \\
\hline Obstacles: Skill & $\begin{array}{l}\text { Extent to which lack of academic skills or poor social- } \\
\text { emotional or physical health impedes academic } \\
\text { success }\end{array}$ \\
\hline Perceived growth & $\begin{array}{l}\text { Student's judgment of his or her own growth in a } \\
\text { variety of skill areas across the time-span of the } \\
\text { university experience }\end{array}$ \\
\hline Satisfaction & $\begin{array}{l}\text { Level of student's satisfaction with the campus } \\
\text { climate, the university experience, and the cost- } \\
\text { benefit ratio of that experience }\end{array}$ \\
\hline Technology: Classroom & $\begin{array}{l}\text { Extent to which the student thinks that technology } \\
\text { should be integrated into the classroom setting }\end{array}$ \\
\hline Technology: Daily life & $\begin{array}{l}\text { Time spent using technology for social or } \\
\text { entertainment purposes }\end{array}$ \\
\hline Technology: University success & $\begin{array}{l}\text { Extent to which the student thinks that technology } \\
\text { enhances his or her university experience }\end{array}$ \\
\hline Time expenditures: Academic & Time spent on coursework \\
\hline Time expenditures: Non-academic & $\begin{array}{l}\text { Time spent on activities such as paid work and social } \\
\text { events }\end{array}$ \\
\hline
\end{tabular}


Table 2

Rate of LD in subgroups

\begin{tabular}{|c|c|c|c|c|c|c|}
\hline \multicolumn{7}{|c|}{ Categorical Variables } \\
\hline Variable & $\begin{array}{l}\text { Percentage } \\
\text { ND }\end{array}$ & $\begin{array}{l}\text { Percentage } \\
\text { LD }\end{array}$ & $\mathbf{n}$ & $\begin{array}{l}\text { Chi - } \\
\text { Square }\end{array}$ & df & $\mathbf{p}$ \\
\hline \multicolumn{7}{|l|}{$\begin{array}{l}\text { Demographic } \\
\text { Characteristics }\end{array}$} \\
\hline Ethnicity & & & & 240.1252 & 8 & $<.0001$ \\
\hline African American & 93.88 & 6.12 & 1896 & & & \\
\hline American Indian & 90.10 & 9.90 & 202 & & & \\
\hline Asian & 96.78 & 3.22 & 6485 & & & \\
\hline Hispanic & 93.21 & 6.79 & 2991 & & & \\
\hline Pacific Islander & 93.33 & 6.67 & 90 & & & \\
\hline White & 92.59 & 7.41 & 34292 & & & \\
\hline Multiracial & 92.43 & 7.57 & 1969 & & & \\
\hline International & 96.01 & 3.99 & 3387 & & & \\
\hline Declined to state & 90.12 & 9.88 & 2590 & & & \\
\hline Gender & & & & 3.2302 & 2 & 0.1989 \\
\hline Male & 93.03 & 6.97 & 22040 & & & \\
\hline Female & 93.38 & 6.62 & 34265 & & & \\
\hline SES & & & & 120.9456 & 4 & $<.0001$ \\
\hline Low income or poor & 90.44 & 9.56 & 3244 & & & \\
\hline Working class & 93.12 & 6.88 & 10022 & & & \\
\hline Middle class & 94.13 & 5.87 & 24686 & & & \\
\hline Upper middle class & 92.99 & 7.01 & 16679 & & & \\
\hline Wealthy & 88.82 & 11.18 & 1520 & & & \\
\hline \multicolumn{7}{|l|}{$\begin{array}{l}\text { In-University } \\
\text { Characteristics }\end{array}$} \\
\hline Declared a Major & & & & 22.5631 & 1 & $<.0001$ \\
\hline No & 94.25 & 5.75 & 11221 & & & \\
\hline Yes & 92.99 & 7.01 & 45091 & & & \\
\hline $\begin{array}{l}\text { Degree Anticipated } \\
\text { Spring or Summer }\end{array}$ & & & & 1.5459 & 1 & 0.2137 \\
\hline Probably no & 93.32 & 6.68 & 43235 & & & \\
\hline Probably yes & 93.01 & 6.99 & 13030 & & & \\
\hline Level in School & & & & 44.7220 & 3 & $<.0001$ \\
\hline Freshman & 94.13 & 5.87 & 7746 & & & \\
\hline Sophomore & 94.21 & 5.79 & 12011 & & & \\
\hline Junior & 92.46 & 7.54 & 14082 & & & \\
\hline Senior & 92.93 & 7.07 & 22003 & & & \\
\hline Living Arrangement & & & & 258.6801 & 6 & $<.0001$ \\
\hline Live alone & 90.92 & 9.08 & 5396 & & & \\
\hline Student room mate & 94.18 & 5.82 & 40135 & & & \\
\hline Nonstudent room mate & 88.95 & 11.05 & 1991 & & & \\
\hline
\end{tabular}

Learn Disabil Res Pract. Author manuscript; available in PMC 2017 May 01. 


\begin{tabular}{lllllll}
\hline \multicolumn{5}{c}{ Categorical Variables } & & \\
Variable & $\begin{array}{l}\text { Percentage } \\
\text { ND }\end{array}$ & $\begin{array}{l}\text { Percentage } \\
\text { LD }\end{array}$ & $\mathbf{n}$ & $\begin{array}{l}\text { Chi - } \\
\text { Square }\end{array}$ & df & p \\
\hline Share w/ family & 93.15 & 6.85 & 4980 & & & \\
Single parent & 85.53 & 14.47 & 228 & & & \\
Sig other w/ children & 90.35 & 9.65 & 860 & & & \\
Sig other no children & 87.66 & 12.34 & 1256 & & & \\
Matriculation & & & & 302.8785 & 2 & $<.0001$ \\
Freshman & 94.16 & 5.84 & 44908 & & & \\
Transfer & 89.42 & 10.58 & 10209 & & & \\
Other & 91.46 & 8.54 & 1195 & & & \\
Resident & & & & 28.9944 & 1 & $<.0001$ \\
In-state & 92.91 & 7.09 & 40654 & & & \\
Out-of-state & 94.24 & 5.76 & 13929 & & & \\
Year First Registered & & & & 65.2374 & 1 & $<.0001$ \\
Before 2009 & 86.72 & 13.28 & 949 & & & \\
2009 or later & 93.36 & 6.64 & 55349 & & & \\
\hline
\end{tabular}

\begin{tabular}{|c|c|c|c|c|c|c|c|c|c|}
\hline \multicolumn{10}{|c|}{ Continuous Variables } \\
\hline & & ND & & & LD & & & & \\
\hline Variable & $\mathbf{N}$ & Mean & SD & $\mathbf{N}$ & Mean & SD & Variances & $\mathbf{T}$ & $\mathbf{P}$ \\
\hline \multicolumn{10}{|c|}{ Demographic Characteristic } \\
\hline Age & 52494 & 21.14 & 3.77 & 3802 & 22.30 & 5.02 & Unequal & -13.87 & $<.0001$ \\
\hline \multicolumn{10}{|c|}{ In-University Characteristics } \\
\hline $\begin{array}{l}\text { Total units: } \\
\text { Completed }\end{array}$ & 50319 & 77.24 & 41.82 & 3644 & 79.54 & 40.43 & Unequal & -3.31 & 0.0009 \\
\hline $\begin{array}{l}\text { Total units: } \\
\text { Current } \\
\text { institution }\end{array}$ & 29884 & 53.84 & 36.37 & 2375 & 52.26 & 35.26 & Unequal & 2.09 & 0.0366 \\
\hline
\end{tabular}


Table 3

Models for each of the $\mathbf{1 8}$ constructs of university experience with disability status as a covariate

\begin{tabular}{|c|c|c|c|c|c|c|}
\hline Construct & $\mathbf{n}$ & Variable & Beta & S.E. & $\begin{array}{l}\text { Test } \\
\text { Statistic }\end{array}$ & $\mathbf{P}$ \\
\hline $\begin{array}{l}\text { Active } \\
\text { engagement }\end{array}$ & 30963 & Disability & 0.093 & 0.016 & 5.89 & $<.0001$ \\
\hline Bias & 5340 & Disability & 0.334 & 0.030 & 11.17 & $<.0001$ \\
\hline Difficulty with assignments & 30980 & Disability & 0.268 & 0.016 & 17.06 & $<.0001$ \\
\hline $\begin{array}{l}\text { Enriched academic } \\
\text { experience }\end{array}$ & 7416 & Disability & 0.048 & 0.020 & 2.35 & 0.0190 \\
\hline Faculty contact & 30996 & Disability & 0.103 & 0.011 & 9.14 & $<.0001$ \\
\hline Goal & 5441 & Disability & -0.021 & 0.029 & -0.75 & 0.4551 \\
\hline GPA & 30821 & Disability * Age & & & 24.47 & $<.0001$ \\
\hline Major & 25886 & Disability & 0.036 & 0.051 & 3.30 & 0.0010 \\
\hline $\begin{array}{l}\text { Obstacles: } \\
\text { Financial }\end{array}$ & 30987 & Disability $*$ Age & & & 12.28 & 0.0005 \\
\hline Obstacles: Non-academic & 7220 & Disability & 0.161 & 0.032 & 5.05 & $<.0001$ \\
\hline Obstacles: Skill & 7223 & Disability & 0.382 & 0.030 & 15.67 & $<.0001$ \\
\hline Perceived growth & 30614 & Disability & -0.023 & 0.011 & -2.06 & 0.0398 \\
\hline Satisfaction & 5387 & Disability & -0.210 & 0.030 & -7.05 & $<.0001$ \\
\hline Time expenditure: Academic & 30648 & Disability* Age & & & 11.45 & 0.0007 \\
\hline $\begin{array}{l}\text { Time expenditure: } \\
\text { Non-academic }\end{array}$ & 30952 & Disability* Age & & & 9.33 & 0.0023 \\
\hline $\begin{array}{l}\text { Technology: } \\
\text { Daily life }\end{array}$ & 1007 & Disability & -0.028 & 0.054 & -0.52 & 0.6024 \\
\hline Technology: Classroom & 826 & Disability & 0.024 & 0.086 & 0.27 & 0.7842 \\
\hline Technology: Success & 910 & Disability & 0.163 & 0.090 & 1.80 & 0.0718 \\
\hline
\end{tabular}


Table 4

Rate of accommodations in subgroups

\begin{tabular}{|c|c|c|c|c|c|c|}
\hline \multirow{3}{*}{ Variable } & \multicolumn{3}{|c|}{ Categorical Variables } & \multirow{3}{*}{$\begin{array}{l}\text { Chi - } \\
\text { Square }\end{array}$} & \multirow{3}{*}{ df } & \multirow{3}{*}{$\mathbf{P}$} \\
\hline & \multicolumn{2}{|c|}{ Accommodations } & \multirow[t]{2}{*}{$\mathbf{N}$} & & & \\
\hline & \% Without & $\%$ With & & & & \\
\hline \multicolumn{7}{|l|}{$\begin{array}{l}\text { Demographic } \\
\text { Characteristics }\end{array}$} \\
\hline Ethnicity & & & & 7.1107 & 8 & 0.5247 \\
\hline African American & 62.07 & 37.93 & 116 & & & \\
\hline American Indian & 65.00 & 35.00 & 20 & & & \\
\hline Asian & 73.68 & 26.32 & 209 & & & \\
\hline Declined to state & 68.36 & 31.64 & 256 & & & \\
\hline Hispanic & 66.50 & 33.50 & 203 & & & \\
\hline International & 67.41 & 32.59 & 135 & & & \\
\hline Multiracial & 63.76 & 36.24 & 149 & & & \\
\hline Pacific Islander & 83.33 & 16.67 & 6 & & & \\
\hline White & 67.22 & 32.78 & 2541 & & & \\
\hline Gender & & & & 0.0014 & 1 & 0.9700 \\
\hline Male & 67.08 & 32.92 & 1537 & & & \\
\hline Female & 67.14 & 32.86 & 2267 & & & \\
\hline SES & & & & 38.0974 & 4 & $<.0001$ \\
\hline Low income or poor & 69.68 & 30.32 & 310 & & & \\
\hline Working class & 71.01 & 28.99 & 690 & & & \\
\hline Middle class & 69.54 & 30.46 & 1448 & & & \\
\hline Upper middle class & 63.76 & 36.24 & 1170 & & & \\
\hline Wealthy & 50.00 & 50.00 & 170 & & & \\
\hline \multicolumn{7}{|l|}{$\begin{array}{l}\text { In-University } \\
\text { Characteristics }\end{array}$} \\
\hline Declared a Major & & & & 0.0300 & 1 & 0.8625 \\
\hline No & 66.82 & 33.18 & 645 & & & \\
\hline Yes & 67.17 & 32.83 & 3159 & & & \\
\hline $\begin{array}{l}\text { Bachelor's Degree in } \\
\text { Spring or Summer }\end{array}$ & & & & 0.1331 & 1 & 0.7152 \\
\hline Probably no & 66.97 & 33.03 & 2888 & & & \\
\hline Probably yes & 67.62 & 32.38 & 911 & & & \\
\hline Level in School & & & & 1.3138 & 3 & 0.7258 \\
\hline Freshman & 66.81 & 33.19 & 455 & & & \\
\hline Sophomore & 65.47 & 34.53 & 695 & & & \\
\hline Junior & 68.08 & 31.92 & 1062 & & & \\
\hline Senior & 67.14 & 32.86 & 1555 & & & \\
\hline Living Arrangement & & & & 24.9963 & 6 & 0.0003 \\
\hline Live alone & 59.80 & 40.20 & 490 & & & \\
\hline Student room mate & 67.78 & 32.22 & 2334 & & & \\
\hline
\end{tabular}




\begin{tabular}{lllllll}
\hline \multicolumn{5}{c}{ Categorical Variables } & & \\
Variable & Accommodations & N & $\begin{array}{c}\text { Chi }- \\
\text { Square }\end{array}$ & df & P \\
& \% Without & \% With & & & \\
\hline Nonstudent room mate & 75.00 & 25.00 & 220 & & & \\
Share w/ family & 66.86 & 33.14 & 341 & & & \\
Single parent & 75.76 & 24.24 & 33 & & & \\
Sig other w/ children & 63.86 & 36.14 & 83 & & & \\
Sig other no children & 75.48 & 24.52 & 155 & & & \\
Matriculation & & & & 1.1944 & 2 & 0.5503 \\
Freshman & 66.70 & 33.30 & 2622 & & & \\
Transfer & 68.33 & 31.67 & 1080 & & & \\
Other & 64.71 & 35.29 & 102 & & & \\
Residency & & & & 9.9434 & 1 & 0.0016 \\
In-state & 68.78 & 31.22 & 2883 & & & \\
Out-of-state & 62.89 & 37.11 & 803 & & & \\
Year First Registered & & & & 2.1340 & 1 & 0.1441 \\
Before 2009 & 61.11 & 38.89 & 126 & & & \\
2009 or later & 67.33 & 32.67 & 3676 & & & \\
& & & & & & \\
\hline
\end{tabular}

Continuous Variables

Accommodations

\begin{tabular}{|c|c|c|c|c|c|c|c|c|c|}
\hline & & Without & & & With & & & & \\
\hline Variable & $\mathbf{N}$ & Mean & SD & $\mathbf{N}$ & Mean & SD & Variances & $\mathbf{T}$ & $\mathbf{P}$ \\
\hline \multicolumn{10}{|c|}{ Demographic Characteristic } \\
\hline Age & 2552 & 22.190 & 4.84 & 1250 & 22.512 & 5.38 & Unequal & -1.79 & 0.0732 \\
\hline $\begin{array}{l}\text { Total units: } \\
\text { Completed }\end{array}$ & 2455 & 79.782 & 40.00 & 3644 & 79.544 & 40.43 & Equal & 0.51 & 0.6093 \\
\hline $\begin{array}{l}\text { Total units: } \\
\text { Current } \\
\text { institution }\end{array}$ & 1599 & 52.137 & 35.81 & 776 & 52.517 & 34.12 & Equal & -0.25 & 0.8053 \\
\hline
\end{tabular}


Table 5

Models for each of the 18 constructs of university experience with accommodation status as a covariate

\begin{tabular}{|c|c|c|c|c|c|c|}
\hline Construct & $\mathbf{n}$ & Variable & Beta & S.E. & $\begin{array}{l}\text { Test } \\
\text { Statistic }\end{array}$ & $\mathbf{P}$ \\
\hline Active engagement & 2245 & Accommodation & 0.054 & 0.034 & 1.59 & 0.1125 \\
\hline Bias & 436 & Accommodation & 0.1739 & 0.081 & 2.14 & 0.0332 \\
\hline Difficulty with assignments & 2247 & Accommodation & -0.104 & 0.038 & -2.75 & 0.0059 \\
\hline $\begin{array}{l}\text { Enriched academic } \\
\text { experience }\end{array}$ & 513 & Accommodation & -0.019 & 0.045 & -0.42 & 0.6739 \\
\hline Faculty contact & 2250 & Accommodation & 0.126 & 0.023 & 5.42 & $<.0001$ \\
\hline Goal & 447 & Accommodation & -0.007 & 0.065 & -0.10 & 0.9199 \\
\hline GPA & 2232 & Accommodation & 0.037 & 0.050 & 0.75 & 0.4521 \\
\hline Major & 1922 & Accommodation & 0.024 & 0.023 & 1.04 & 0.3000 \\
\hline Obstacles: Financial & 2246 & Accommodation & -0.071 & 0.028 & -2.52 & 0.0119 \\
\hline Obstacles: Non-academic & 495 & Accommodation & 0.041 & 0.071 & 0.58 & 0.5590 \\
\hline Obstacles: Skill & 495 & Accommodation & -0.008 & 0.064 & -0.13 & 0.8959 \\
\hline Perceived growth & 2215 & Accommodation & -0.038 & 0.025 & -1.52 & 0.1278 \\
\hline Satisfaction & 442 & Accommodation & 0.081 & 0.072 & 1.13 & 0.2585 \\
\hline $\begin{array}{l}\text { Time expenditures: } \\
\text { Academic }\end{array}$ & 2230 & Accommodation & 0.081 & 0.038 & 2.13 & 0.0333 \\
\hline $\begin{array}{l}\text { Time expenditures: Non- } \\
\text { academic }\end{array}$ & 2247 & Accommodation & 0.029 & 0.027 & 1.06 & 0.2893 \\
\hline Technology: Classroom & 85 & Accommodation & 0.001 & 0.174 & 0.00 & 0.9964 \\
\hline Technology: Daily life & 105 & Accommodation & 0.1811 & 0.084 & 2.16 & 0.0339 \\
\hline $\begin{array}{l}\text { Technology: University } \\
\text { success }\end{array}$ & 94 & Accommodation & 0.149 & 0.182 & 0.82 & 0.4165 \\
\hline
\end{tabular}

